\title{
Interaction between an invasive decapod and a native gastropod: predator foraging tactics and prey architectural defenses
}

\author{
Rémy Rochette*, Sean P. Doyle, Timothy C. Edgell \\ Department of Biology, University of New Brunswick, Saint John Campus, PO Box 5050, Saint John, \\ New Brunswick E2L4L5, Canada
}

\begin{abstract}
The shell architecture of the intertidal snail Littorina obtusata (L.) is thought to have undergone an adaptive transition in response to invasion of the Gulf of Maine, NW Atlantic, by the European green crab Carcinus maenas (L.). In order to investigate the hypothesis that this morphological transition affects snail fitness, we conducted predation experiments with snail populations showing morphological differences that are hypothesized to have been caused by, and affect resilience to, green crab predation. Our results are consistent with the adaptive-transition hypothesis, but they reveal more varied predator foraging tactics and prey defensive attributes than previously considered. Crabs killed smaller and less heavily-armored snails by breaking their shell, but killed larger and more heavily-armored individuals using a fairly complex 'shell-entry' tactic, which we refer to as 'winkling'. The snail population which suffered lower mortality from green crab predation apparently obtained protection from crushing by having a thicker, more massive shell, and from winkling by having a smaller aperture. Our study provides evidence that the morphological transition undergone by L. obtusata following the green crab's invasion of the NW Atlantic is adaptive, and raises new questions regarding the phenotypic basis of this recent ecological interaction.
\end{abstract}

KEY WORDS: Invasion biology - Anti-predator defenses - Gastropod shell - Littorina obtusata · Green crab $\cdot$ Carcinus maenas $\cdot$ Predator-prey relationship

Resale or republication not permitted without written consent of the publisher

\section{INTRODUCTION}

The study of geographic phenotypic variation has greatly contributed to our understanding of ecological and evolutionary patterns and processes (Endler 1977, 1986, Foster \& Endler 1999). In the marine environment, for example, such studies have revealed that gastropod populations exposed to high levels of shellcrushing predation often produce stronger and more ornamented shells that are more resistant to breakage (e.g. Kitching et al. 1966, Hughes \& Elner 1979, Currey \& Hughes 1982, Vermeij 1982, Palmer 1985, Johannesson 1986, Thomas \& Himmelman 1988, Boulding et al. 1999, Trussell 2000b), whereas populations exposed to lower levels of like predation typically make thinner and less defended shells, presumably because these are less costly (Palmer 1981, 1992).
There exist 2 correlative lines of evidence suggesting that invasion of the NW Atlantic by the European green crab Carcinus maenas (L.), which is a known molluskan predator (Elner 1981), caused changes in the shell morphology of Littorina obtusata (L.) (see also Vermeij 1982 for suggestion of an adaptive phenotypic change in the dogwhelk Nucella lapillus). Firstly, shells collected in the Gulf of Maine (GoM) in the late 1800 s, i.e. prior to the green crab's invasion, had relatively high spires and thin walls, whereas shells collected from the same localities in 1982 to 1984, i.e. 50 to $100 \mathrm{yr}$ after the invasion, had lower spires with thicker walls (Seeley 1986). Secondly, contemporary snail populations found closer to the initial site of green crab introduction in the southern GoM have thicker shells than snails from more northern sites (Trussell 2000b). 
This morphological transition of Littorina obtusata toward thicker shell wall and lower spire is estimated to have occurred within fewer than 100 generations (L. obtusata has $\sim 1$ generation $\mathrm{yr}^{-1}$ ), and was first interpreted as evidence of rapid evolution by Darwinian selection (Seeley 1986). More recent studies, however, suggest that it may at least partly be due to phenotypic plasticity; L. obtusata raised in the presence of effluents from green crabs feeding on conspecific snails develop a thicker shell than individuals raised in the absence of these effluents (Trussell 1996, 2000a). It remains unclear to what extent this historical shift and contemporary variation in L. obtusata shell phenotype are due to selection on genetic variation in shell thickness (Seeley 1986), selection for different reaction norms (Trussell \& Smith 2000), or phenotypic plasticity with no genetic response.

Despite the considerable interest generated by this new ecological interaction (e.g. Seeley 1986, Trussell 1996, 2000a,b, Trussell \& Smith 2000, Trussell \& Nicklin 2002, Smith 2004), the adaptive value of the snails' morphological changes has not been rigorously investigated. Experiments using mechanical crushing devices have shown that a greater force is required to crack thicker than thinner Littorina obtusata shells (Trussell 2000a, b), but the full ecological implication of these findings is uncertain considering the complex and diverse predatory tactics crabs use to kill prey (e.g. Elner \& Raffaelli 1980, Johannesson 1986). Using field-tethering and laboratory-predation experiments, Seeley (1986) found that 2 L. obtusata populations with relatively low spires and thick shells were better defended against shell-crushing predators than conspecifics from 2 populations with higher spires and thinner shells, but the mechanism(s) underlying these differences is unclear. Seeley (1986) hypothesized that lower-spired L. obtusata shells were less susceptible to crushing predators because the thinnest and most vulnerable shell whorls (those produced by the juvenile) were better enclosed in the thicker 'adult whorls' than in snails with higher spires. However, the greater resistance of low-spired shells may have been due to their thickness, which co-varied with spire height, instead of (or in addition to) the height of their spire. It should also be noted that the adaptive value of different shell attributes may depend on the relative size of the combatants, but no study has yet investigated the attack mechanism of green crabs on different-size L. obtusata snails. Finally, in addition to structural properties of the shell, chemical defenses might also affect susceptibility to crab predation, but no study has yet compared the 'palatability' of L. obtusata snails from different populations.

In this study, we (1) address the hypothesis that Littorina obtusata snails from a population with a seemingly better-defended phenotype are more resistant to predation by Carcinus maenas than 'less-defended' conspecifics, (2) investigate the contribution of spire height, shell thickness, aperture area and tissue palatability to inter-population differences in snail vulnerability, and (3) determine whether snail vulnerability and crab predatory tactics vary with snail size. Our results indicate that contemporary variation in $L$. obtusata shell thickness (but probably not spire height nor palatability) significantly affects shell-crushing predation by the invasive green crab in the GoM, and reveal a novel predatory tactic ('winkling') and prey architectural defense (smaller aperture area) that may significantly affect the nature and outcome of this recent ecological interaction.

\section{MATERIALS AND METHODS}

Study sites. We collected Littorina obtusata snails and Carcinus maenas crabs from 2 sites where shell thickness of L. obtusata is close to (but within) the upper and lower extremes previously reported for this species in the GoM (Trussell 2000b): Quoddy Head, Maine $\left(44^{\circ} 48.83^{\prime} \mathrm{N}, 66^{\circ} 57.06^{\prime} \mathrm{W}\right)$, and Lobster Cove, Massachusetts $\left(42^{\circ} 33.84^{\prime} \mathrm{N}, 70^{\circ} 46.21^{\prime} \mathrm{W}\right)$. These sites are separated by approximately $450 \mathrm{~km}$ of coastline, and will hereafter be referred to as northern and southern sites, respectively.

Preliminary sampling. We undertook preliminary sampling of snails in July 2002 to confirm previously reported (Trussell 2000b) differences in shell thickness between our 2 study sites, and to determine whether thickness varied with intertidal height. At both sites, we collected snails near the lower $(0.25$ and $1.70 \mathrm{~m}$ above chart datum for southern and northern sites, respectively) and upper (1.10 and $3.25 \mathrm{~m}$ ) limits of their vertical distribution. At each tidal level, we first placed an $8 \mathrm{~m}$ transect and then used randomly positioned quadrats $(0.25 \times 0.25 \mathrm{~m})$ to sample approximately 100 snails larger than $\sim 4 \mathrm{~mm}$ in total shell height, measured as the maximum distance between the shell apex and outer lip of the aperture (Reid 1996, p. 9).

Main sampling. Preliminary sampling (above) revealed that shell thickness was independent of tidal height for southern, but not northern, snails; differences in shell thickness between upper- and lowerintertidal snails in the north were, however, small compared to differences between northern and southern snails. For this study, we compared vulnerability of lower-intertidal snails from the northern site, which had a heavier shell than high-intertidal conspecifics (a more conservative test of our hypothesis), to that of upper-intertidal snails from the south (because they were more abundant). In September 2002 we randomly sampled approximately 1000 southern and 1000 
northern snails. At both sites, we also collected approximately 30 Carcinus maenas crabs measuring 30 to $48 \mathrm{~mm}$ in carapace width by snorkelling in the shallow subtidal and flipping rocks exposed at low tide. Snails and crabs were transported in cooled containers with wet brown algae (Ascophyllum nodosum [L.] Le Jolis) to a laboratory facility.

Laboratory holding conditions. We housed the animals in a 25001 re-circulating seawater facility on the Saint John campus of the University of New Brunswick, Canada. Snails and crabs were held in separate 301 aquaria, each equipped with an air stone, water supply, and a mesh lid. Within the crab holding tanks, individuals were further physically isolated in circular plastic containers $(5 \mathrm{~cm}$ height, $10 \mathrm{~cm}$ diameter) to prevent fighting and injury; we drilled a $1 \mathrm{~cm}$ diameter hole through the top and bottom of each container to facilitate water flow. Snails were provided with fresh Ascophyllum nodosum every $\sim 14 \mathrm{~d}$ as food, and crabs were fed 1 Littorina littorea (L.) snail ( 8 $\mathrm{mm}$ shell height) every $2 \mathrm{~d}$. Filtered ( 5 to $10 \mu \mathrm{m}$ ) seawater at $12 \pm 1^{\circ} \mathrm{C}$ and $33 \pm 2$ ppt was pumped into each aquarium at $\sim 31 \mathrm{~min}^{-1}$ for $1 \mathrm{~min}$ every $5 \mathrm{~min}$. Fecal material was siphoned from the bottom of each aquarium every $14 \mathrm{~d}$.

Predation experiment. To assess inter-population differences in Littorina obtusata susceptibility to green crab predation, we conducted laboratory predation experiments between October 19 and 30, 2002, which involved all 4 combinations of predator and prey populations. In each replicate, a single male or female crab from a given population was caged with 8 differentsized snails (one for each $1 \mathrm{~mm}$ shell height increment from 5 to $13 \mathrm{~mm}$ ) from a single population, in a $3.5 \times$ $13.5 \times 5 \mathrm{~cm}$ plastic chamber with perforated lid. Every 5 min, newly filtered seawater $\left(12 \pm 1^{\circ} \mathrm{C}\right.$ and $\left.33 \pm 2 \mathrm{ppt}\right)$ was pumped into the bottom of each cage at a rate of $\sim 0.15 \mathrm{l} \mathrm{min}^{-1}$ for $1 \mathrm{~min}$. We only used crabs measuring 30 to $48 \mathrm{~mm}$ carapace width, and did not use individuals that were visibly regenerating a lost chela. The allocation of crabs to the different cages was random, with the condition that each of the 8 treatment combinations $(2$ snail populations $\times 2$ crab genders $\times 2$ crab populations) was replicated 6 to 7 times. The size of crabs used in the different cages was similar for the 2 snail populations $\left(F_{1,42}=1.67, \mathrm{p}=0.20\right)$ and crab populations $\left(F_{1,42}=1.89, \mathrm{p}=0.18\right)$, and for male and female crabs $\left(F_{1,42}=0.62, \mathrm{p}=0.44\right)$; there was also no significant interaction among these factors (all $\mathrm{p}>0.25$ ).

During each trial, we monitored the cages every day and recorded the fate of the 8 different-sized snails after $3 \mathrm{~d}$. Snails were assigned as 'not killed' if they were actively crawling, or if they were inactive but responded to prodding. They were classified as 'killed' if their shell had been broken into pieces (in which case no soft tissues remained) or if the shell was intact but the snail's body (or part of it) had been removed, which was confirmed by breaking and inspecting the shell. We were not able to determine the exact mechanism by which each snail was killed, but a qualitative assessment of shell damage and follow-up observations (described below) indicated at least 2 very different mechanisms (see Results).

Statistical analyses. We analyzed the mortality data with a 3-way factorial ANOVA in which snail population, crab gender and crab population were fixed-effect factors, and number of snails dead at the end of the $3 \mathrm{~d}$ experimental period was the dependent variable. We used Bartlett and Shapiro-Wilk W tests applied on model residuals to test homoscedasticity and normality assumptions, respectively. We conducted this analysis on log-transformed data, as these best conformed to model assumptions (homoscedasticity: $F_{7, \infty}=0.62, \mathrm{p}=$ 0.74 ; normality: $\mathrm{W}=0.94, \mathrm{p}=0.023)$. We interpreted the results of this analysis even though it violated the normality assumption, because ANOVAs are robust to such small assumption violations (Zar 1984) and resulting F ratios were either highly significant or clearly statistically nonsignificant (see 'Results').

We conducted a similar analysis of the mean size of snails killed in each cage. Data for male and female crabs were pooled for this analysis, to circumvent the problem of small sample size ( $\mathrm{n}=2$ to 3 ) for trials involving southern snails; 13 of the 26 crabs that were tested with southern snails failed to kill a single individual, yielding empty cells in the analysis of the 'mean size killed'. Such pooling seemed reasonable, because male and female crabs killed similar numbers of snails, and both genders mainly killed smaller individuals (see 'Results'). The analysis of the mean size of snails killed was conducted on the raw data, which satisfied the normality ( $\mathrm{W}=0.95, \mathrm{p}=0.19)$ and homoscedasticity $\left(F_{3, \infty}=1.60, \mathrm{p}=0.19\right)$ assumptions.

All statistical analyses were done with $\mathrm{JMP}^{\circledR}$ v.5 software.

Observations of crabs feeding on snails. To elucidate the different mechanisms crabs used to kill snails, we made additional observations in larger 301 tanks in which snails of different sizes and populations were offered to green crabs. Two male and 2 female crabs from each population were presented with snails measuring $\sim 10$ to $13 \mathrm{~mm}$ shell height and observed for $\sim 30$ min on 10 separate occasions (total of $\sim 40 \mathrm{~h}$ ). Some of the kills were recorded by digital video to document an unexpected predatory tactic that was probably responsible for the recovery of dead snails with intact shells during the main experiment.

Palatability experiment. We conducted a second predation experiment to determine if snails from both populations were equally palatable to crabs. The general setup and size of animals used was as in the main exper- 
iment, except that the shell of snails was cracked and removed before the body was placed in a container with a crab. We ran 5 to 6 replicates of each of the 8 treatment combinations, and recorded snails consumed after $1 \mathrm{~h}$.

Snail morphometrics. To quantify inter-population differences in shell characteristics, we haphazardly selected 38 snails spanning a broad size range, and measured their shell length, shell thickness and spire height using digital calipers $( \pm 0.01 \mathrm{~mm})$, and aperture area using image analysis software $\left( \pm 0.001 \mathrm{~mm}^{2}\right)$. We measured shell length as the maximum dimension of the shell parallel to the plane of the aperture (see Trussell 1996), and used this as covariate in morphometric analyses; we did not use shell height (as per predation experiment) as covariate, because this measure encompasses, and is thus dependent upon, the height of the shell's spire, which was one of the dependent variables. Although the relation between shell length and shell height differed significantly between northern and southern snails, this difference was very small, not very consistent (see 'Results') and most likely inconsequential to the interpretation of the large population effects observed during the predation experiment (see 'Discussion'). We measured spire height as the distance between the shell apex and the main body whorl in a plane parallel to the columella, and shell thickness at the outer lip of the aperture, at the point furthest from the columella. To quantify inner aperture area, we first positioned each shell such that the plane of the aperture was parallel to the stage of a Leica ${ }^{\circledR}$ MZ12.5 dissecting scope, and then took an image of the aperture using a QI-Cam ${ }^{\mathrm{TM}}$ camera and Q-Imaging ${ }^{\mathrm{TM}}$ software. Images were then calibrated, and the inner area of each aperture recorded using OpenLab ${ }^{\mathrm{TM}}$ 3.0.4 software.

We ran 3 separate ANCOVAs, all using shell length as the covariate and site as fixed-effect factor, to compare the 2 populations with respect to spire height, shell thickness and aperture area. We used non-transformed values of inner aperture area and shell thickness, but log-transformed spire height as this improved linearity. Slopes were similar between populations for log spire height $\left(F_{1,72}=0.03, \mathrm{p}=0.87\right)$ and shell thickness $\left(F_{1,72}=0.26, \mathrm{p}=0.61\right)$, and these final models were therefore run without the site by covariate interaction term (Hendrix et al. 1982). In contrast, slopes were not parallel for the aperture area data $\left(F_{1,72}=\right.$ 24.10, $\mathrm{p}<0.0001)$, and we investigated this interaction using the Johnson-Neyman technique (Huitema 1980). The Bartlett test applied to residuals indicated that all 3 models satisfied the homoscedasticity assumption (shell thickness: $F_{1, \infty}=0.06, \mathrm{p}=0.81$; inner aperture area: $F_{1, \infty}=0.41, \mathrm{p}=0.52$; log spire height: $F_{1, \infty}=2.68$, $\mathrm{p}=0.10)$. The Shapiro-Wilk test indicated that models for log spire height ( $\mathrm{W}=0.979, \mathrm{p}=0.59$ ) and aperture area $(\mathrm{W}=0.982, \mathrm{p}=0.71)$ satisfied the normality assumption, but the shell thickness model did not ( $\mathrm{W}=$ $0.954, p=0.02$ ). Transformations were not successful in remedying this violation. We nevertheless interpret the results of this analysis, because ANOVAs are robust to such small assumption violations (Zar 1984) and the observed effect size (i.e. differences in shell thickness between sites) was extremely pronounced.

\section{RESULTS}

\section{Palatability experiment}

All un-shelled snails were consumed within $1 \mathrm{~h}$ of being offered to crabs.

\section{Main experiment}

A total of 135 snails were killed during the experiment (34\% of 400 snails offered to crabs), 115 from the northern population and only 20 from the southern population. The effect of snail population on mortality was highly significant ( $\mathrm{p}<0.0001)$, of great magnitude (Fig. 1), and consistent for both genders and populations of crabs (Table 1).

Snail mortality also depended on crab origin, as southern crabs killed 1.5 times more snails than northern crabs (Fig. 1). Although the effect of crab population was less pronounced than that of snail population, it was statistically significant (Table $1, p=0.006$ ). Mortality rates (crushed + empty shells) did not differ between cages with male and female crabs, and none of the higher-order effects were significant (Table 1).

Snail population also had a highly significant $\left(F_{1,33}=\right.$ 24.93, p $<0.0001$ ) effect on the mean size of snails killed; crabs succeeded in killing larger snails from the northern, than the southern, population (Fig. 2). The mean size of snails killed was below the mean size of snails offered (Fig. 2), indicating that crabs were more successful at killing the smaller snails. The size of snails killed (crushed + empty shell) was independent of crab population $\left(F_{1,33}=0.20, \mathrm{p}=0.65\right)$, and the interaction between crab and snail population was also not significant $\left(F_{1,33}=0.62, \mathrm{p}=0.44\right)$.

\section{Predatory mechanism}

At the end of the $3 \mathrm{~d}$ experiment period, many snails had their shell broken into pieces, and their body was completely missing. These snails' shells had presumably been crushed by the crabs' master chela, and their bodies consumed after being exposed. However, many snails recovered dead at the end of the experiment had 


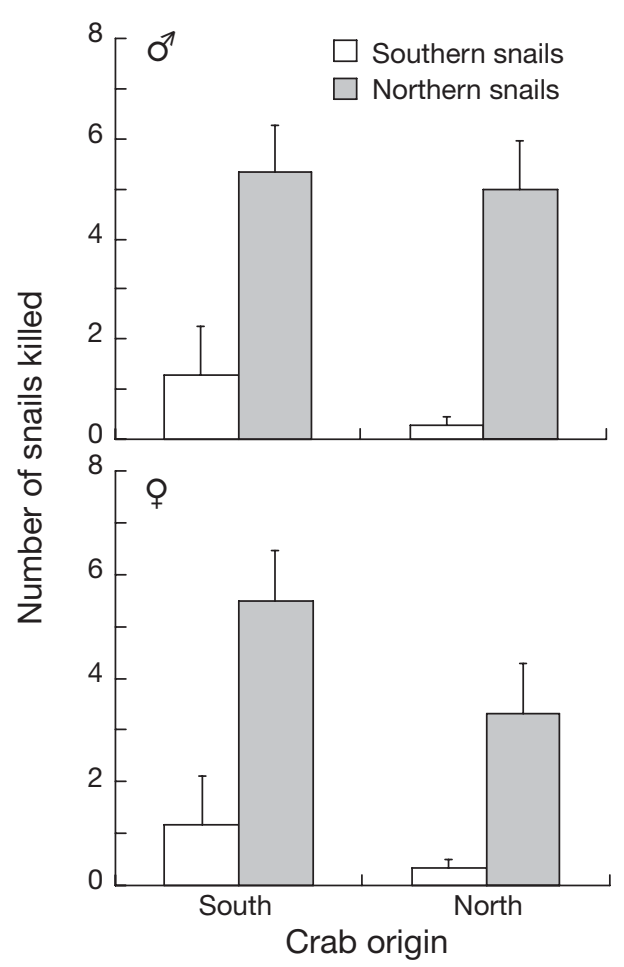

Fig. 1. Littorina obtusata. Laboratory predation experiment. Mean (+SE) number of southern and northern snails killed when offered to southern and northern male (top panel) or female (bottom panel) European green crabs Carcinus maenas

Table 1. Littorina obtusata. Results of 3-way ANOVA testing for effects of snail population, crab Carcinus maenas population, and crab gender on number of snails killed. Analysis conducted on log-transformed data

\begin{tabular}{|lcrrr|}
\hline Source of variation & MS & df & \multicolumn{1}{c|}{$F$} & \multicolumn{1}{c|}{$\mathrm{p}$} \\
\hline Snail population (SP) & 3.6159 & 1 & 106.414 & $<0.0001$ \\
Crab population (CP) & 0.2913 & 1 & 8.572 & 0.0055 \\
Crab gender (CG) & 0.0238 & 1 & 0.700 & 0.4076 \\
SP $\times$ CP & 0.0270 & 1 & 0.796 & 0.3774 \\
SP $\times$ CG & 0.0038 & 1 & 0.112 & 0.7397 \\
CP $\times$ CG & 0.0061 & 1 & 0.178 & 0.6753 \\
SP $\times$ CP $\times$ CG & 0.0488 & 1 & 1.436 & 0.2376 \\
Error & 0.0340 & 42 & & \\
\hline
\end{tabular}

an intact shell. Follow-up observations revealed a complex behavior used by crabs to remove snail soft tissues by entrance through the aperture (see supplementary video material, available at www.int-res.com/articles/ suppl/m330p179_video.wmv). The shell is first oriented such that the dactylus of the major claw is inserted into the aperture to probe the body of the snail, which sometimes results in the body being successfully caught between the crab's dactylus and the inside of the shell's main body whorl. When this occurs, the master claw then rotates to drag the body outwards, pressing it against the inner wall of the shell, while the minor claw

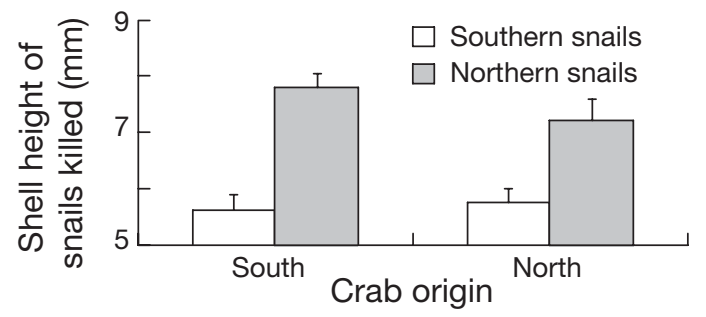

Fig. 2. Littorina obtusata. Laboratory predation experiment. Mean (+SE) shell height of southern and northern snails killed when offered to southern and northern European green crabs Carcinus maenas. Data for male and female crabs was pooled (i.e. crab gender was not included in analysis), to circumvent problem of small sample size for trials involving southern snails (see 'Materials and methods: Statistical analyses'). Mean size of snails (range 5 to $13 \mathrm{~mm}$ ) offered to crabs during experiment was $9 \mathrm{~mm}$

applies counter-rotational force to maintain the shell in position. Once the snail's body is successfully pulled near the outer aperture lip, it is either grasped by the mandibles or pinched between the dactylus and propodus of the major claw, and then transferred to the mandibles. The crab then extracts the snail's body from its shell by clasping the fleshy parts within its mouthparts and pushing away the shell with both claws. Occasionally the snail's entire body was successfully pulled out by this technique, but more frequently the visceral mass would break off and remain inside the shell. We refer to this complex predatory behavior as 'winkling', which in culinary vernacular describes 'the process of extracting a winkle from its shell', and more generally signifies 'to obtain or draw out by effort' (Merriam-Webster Collegiate Dictionary 2005).

The total number of snails killed by crushing $(n=67)$ versus winkling ( $\mathrm{n}=68)$, as estimated from shell remains (see above), was nearly identical. However, the incidence of winkling relative to crushing was markedly greater for larger individuals, as shown for northern snails in Fig. 3. A similar graphical analysis was less useful for southern snails, as only 20 of these were killed, but the average size of southern snails crushed (5.4 mm shell height, $\mathrm{n}=13$ ) was significantly (Welch ANOVA for unequal variances, $p=0.039$ ) smaller than that of individuals that were winkled (7.1 mm, $\mathrm{n}=7$ ), which is consistent with results observed for northern snails.

\section{Snail morphometrics}

We found significant differences between northern and southern snails in size-adjusted values of the 3 traits measured (Fig. 4). Southern snails had a significantly thicker shell $\left(F_{1,72}=36.21, \mathrm{p}<0.0001\right)$ and a lower spire $\left(F_{1,72}=7.35, \mathrm{p}=0.008\right)$ at a given shell length than northern conspecifics (Fig. 4). For example, 


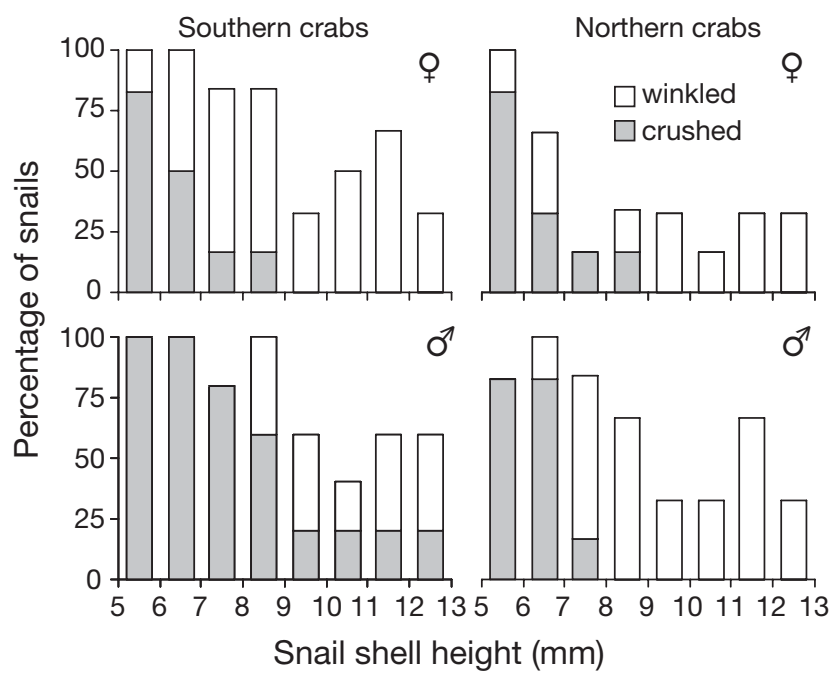

Fig. 3. Littorina obtusata. Laboratory predation experiment. Proportion of different-sized (shell height) northern snails crushed versus winkled (i.e. pulled out without shell being broken) when killed by female and male European green crabs Carcinus maenas. A similar graphical representation was less useful for southern snails, because too few were killed, but for these too the size of snails winkled was greater than that of individuals crushed (see 'Results')

predicted shell thickness for 6 and $12 \mathrm{~mm}$ snails was 17 and $7 \%$ greater for southern than northern snails, respectively, and predicted spire height for same-sized snails was 11 and $13 \%$ greater for northern than southern snails, respectively. Note that although differences in spire height were significant, size-adjusted values overlapped considerably between populations (Fig. 4).

The inner aperture area of southern and northern snails also differed (Fig. 4), but this was not true for all sizes of snails (slopes were not parallel: $F_{1,72}=25.00, \mathrm{p}<$ 0.0001). The Johnson-Neyman technique revealed that below approximately $5.75 \mathrm{~mm}$ in shell length, the aperture area of northern and southern snails did not differ significantly, but above this value, southern snails had a significantly $(p<0.05)$ smaller aperture than individuals from the north. The inter-population difference in aperture area increased with increasing snail size (Fig. 4), even in relative terms, being approximately $12 \%$ at $6 \mathrm{~mm}$ and $21 \%$ at $12 \mathrm{~mm}$ shell length.

There was a very strong correlation between shell height and shell length for both populations $(r=0.995)$. The lines for northern and southern snails had similar slopes $\left(F_{1,46}=0.55, \mathrm{p}=0.464\right)$, and observed values for the 2 populations overlapped considerably (Fig. 5). The difference in elevation of these lines was marginally significant $\left(F_{1,46}=6.78, \mathrm{p}=0.012\right)$, but this difference was very small; for example, predicted shell length differed by only $\sim 0.10$ to $0.25 \mathrm{~mm}$ between southern and northern snails over the size range used, which represents a 1 to $2 \%$ difference. Interestingly, not only was
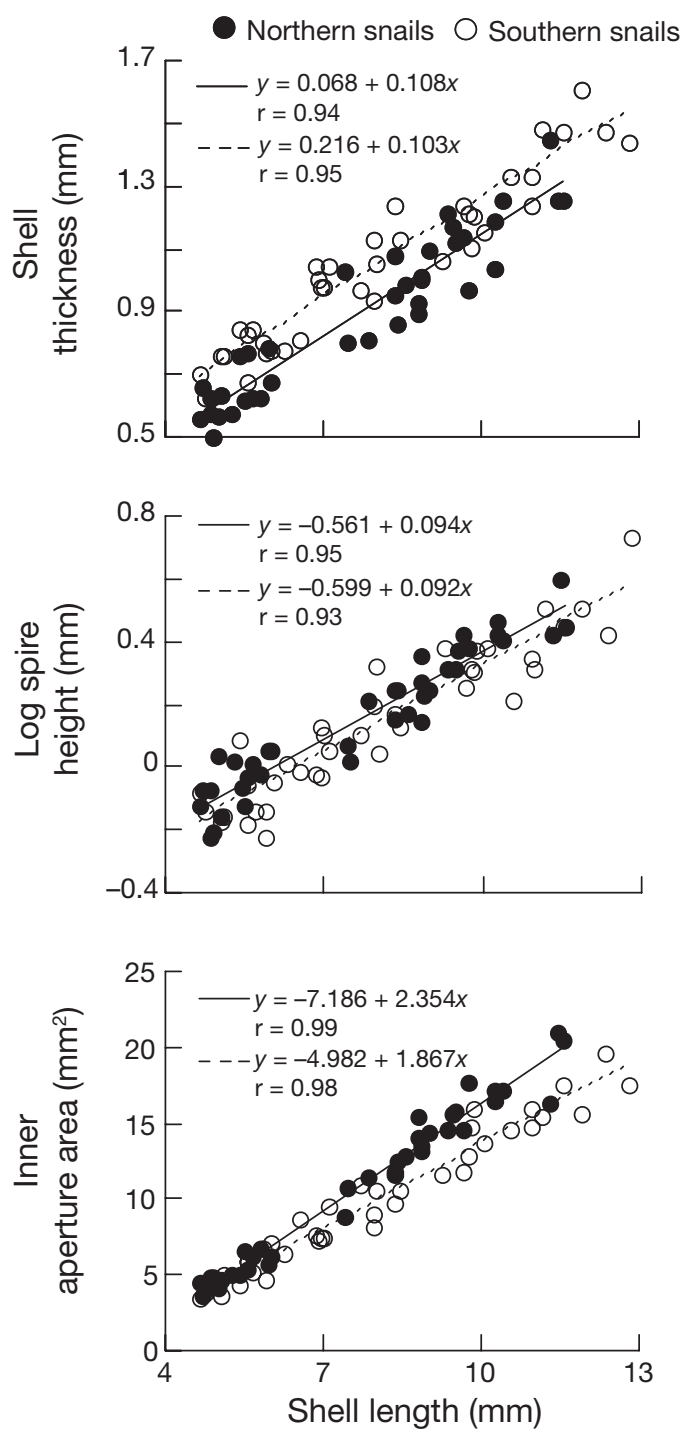

Fig. 4. Littorina obtusata. Morphometric analyses. Relation between shell length and 3 structural properties of southern (dashed line) and northern (solid line) snail shells (thickness, spire height, and inner aperture area), which may affect susceptibility to predation by the European green crab

Carcinus maenas. All regressions significant at $\mathrm{p}<0.001$

the relation between shell height and shell length extremely similar for the 2 populations, but both measurements were also comparable in absolute terms, which reflects the relatively globose shape of these shells.

\section{DISCUSSION}

\section{Inter-population differences in snail vulnerability}

Our study revealed a marked difference in vulnerability of 2 Littorina obtusata snail populations to predation by the invasive green crab Carcinus maenas. 


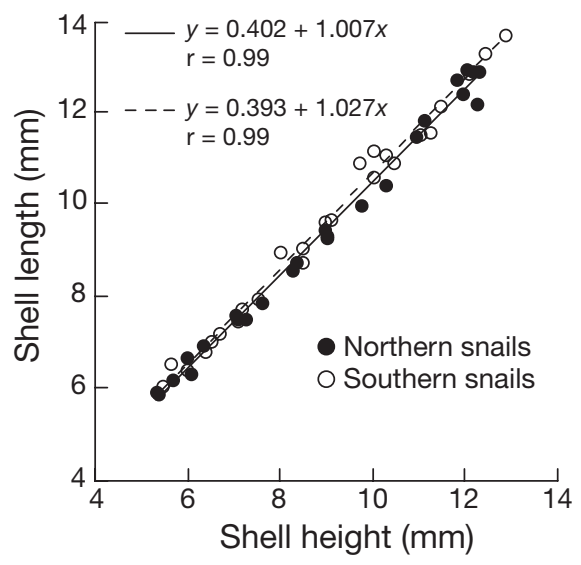

Fig. 5. Littorina obtusata. Morphometric analyses. Relation between shell height and shell length of southern (dashed line) and northern (solid line) snails used in this study

These 2 populations roughly encompass the range of shell thickness documented for L. obtusata in the GoM (Trussell 2000b). As predicted, the thinner-shelled and higher-spired L. obtusata from the northern GoM were more vulnerable than their thicker-shelled and lower-spired conspecifics from the southern GoM; northern and southern snails were killed in a ratio of 4:1 (male crabs) and 5:1 (female crabs) by northern crabs, and 18:1 (male crabs) and 10:1 (female crabs) by southern crabs.

Although not the focus of this study, it is also worth noting that southern crabs, which are sympatric with better-defended snails, were markedly more efficient at killing snails of both populations than northern conspecifics (see also Smith 2004).

\section{Phenotypic basis of inter-population differences in vulnerability}

Variation in shell characteristics was probably the cause of inter-population differences in susceptibility to predation. All snails that were offered to green crabs with their shell cracked were eaten within $1 \mathrm{~h}$, indicating that individuals from both populations were similarly and highly palatable to this predator. Although our experiment might not have detected minor differences in palatability that could have manifested within 60 min, such small differences (if they exist) would almost certainly not have caused the large interpopulation differences in mortality observed during the $72 \mathrm{~h}$ main experiment. Escape behavior probably did not contribute to inter-population differences in vulnerability either, because the cages were too small for snails to crawl out of the crabs' reach. Our data suggest that southern snails are better defended against green crabs than northern conspecifics because of the greater thickness of their shell (a defense against crushing) as well as the size of their aperture (a defense against winkling); during our experiment, $27 \%$ of northern snails were crushed and $33 \%$ were winkled, compared to only 7 and $3 \%$, respectively, for southern snails.

\section{Defense against crushing}

Previous experiments with mechanical crushing devices have shown that thicker-shelled Littorina obtusata populations in the GoM are more resistant to breakage than thinner-shelled populations (Trussell 2000a,b), and our study indicates that these differences are ecologically relevant, that is they significantly affect resistance to green crab shell-crushing predation (see also Seeley 1986, Smith 2004). Indeed, crabs were frequently observed to put aside thicker-shelled snails after unsuccessful attempts at cracking their shell. We believe the principal reason why southern snails were less susceptible to breakage is that they have a thicker (and hence stronger) shell than northern individuals.

Green crabs (Hughes \& Elner 1979, Elner \& Raffaelli 1980, Johannesson 1986) and other decapods (Vermeij 1987) sometimes kill gastropods by crushing their thinner sub-apical shell whorls, and Seeley (1986) suggested that higher-spire populations of Littorina obtusata might be particularly susceptible to this predatory tactic. Whereas lower-spired shells may be less susceptible to shell-crushing predation, higherspired ones probably afford greater internal volume, and hence may enable snails to attain larger body sizes, which may be advantageous because intraspecific variation in body size can affect fecundity in littorinids (e.g. Hughes \& Answer 1982). According to the spire-height hypothesis, the difference in vulnerability of our 2 snail populations could be due to variation in spire height, because our southern snails, which were less susceptible to shell-crushing, did have a lower spire than their northern conspecifics. However, we do not believe spire height contributed significantly to inter-population differences in shell breakage during our study. During our $\sim 40$ h of observation, we did not see green crabs crush sub-apical shell whorls without having previously or simultaneously cracked the main body whorl. Snails from our 2 populations have rotund shells with remarkably low spires, which we believe afforded crabs insufficient surface to leverage with their large chelae. It would appear particularly unlikely that inter-population differences in spire height could have significantly affected susceptibility to spire-crushing, because this difference is small (predicted difference of 0.1 to $0.2 \mathrm{~mm}$ for snails of 5 to $9 \mathrm{~mm}$ 
shell height, where most shell-crushing occurred) and not consistent (Fig. 4). Also, the clear pattern of decreasing susceptibility to crushing with increasing shell size is inconsistent with the spire height hypothesis; if a lower-spire shell was advantageous because it better protected earlier and weaker shell material, then we would not expect snails to gradually become less susceptible to crushing as they become bigger, because the height of a shell's spire does not decrease as the snail grows. We currently do not know what evolutionary and/or developmental mechanisms are responsible for the small variation in spire height between these 2 snail populations.

Despite our conclusion that spire height was likely to have had little (if any) effect on susceptibility to shellcrushing during our study, we are not suggesting that this trait is never relevant to breakage resistance, nor that it played no role in historical changes in Littorina obtusata's vulnerability to green crabs in the NW Atlantic (Seeley 1986). It is worth noting that whereas Fig. 2 of Seeley (1986) showed roughly 50 to $70 \%$ (3 separate sites) difference in spire height between adult shells collected pre- and post-green crab invasion, our 2 populations only differed by $\sim 10$ to $13 \%$. Furthermore, although our spire height data are not directly comparable, Fig. 1 of Seeley (1986) suggests that shells pre-dating the green crab's invasion had markedly higher spires than either of the populations used in the present study.

\section{Winkling and snail architectural defense}

Green crabs generally killed larger better-armored snails by winkling them, without causing visible damage to the shell itself. When using this technique, the crab would enter the snails' shell via the aperture with a single dactylus, and pry part or all of the snail out by simultaneously pressing its soft parts against the inside of the shell wall and dragging them toward the plane of the aperture, where they could be grasped by the claw or mouth appendages (see 'Results' and supplementary video recordings). That green crabs killed snails by probing their aperture will not surprise researchers studying decapod-gastropod interactions. For example, there are several reports of decapods entering the shell of relatively large gastropods with their entire chela and then grasping and pulling out the prey's soft tissues (e.g. Ebling et al. 1964, Kitching et al. 1966, DeWitt et al. 2000). However, to the best of our knowledge winkling as described here (i.e. using a single dactylus) has previously been reported in one study only, which involved small female green crabs in their native European range preying on Littorina saxatilis (Johannesson 1986). Since conducting the pre- sent study, we have observed green crabs from 2 additional localities in the Bay of Fundy use this technique to kill L. obtusata and (to a lesser extent) L. littorea. The ability to access soft tissue of prey using a single dactyl is significant in that it potentially increases the size range of gastropod prey that decapods can kill by aperture probing.

We believe the greater resilience of southern versus northern snails against winkling was largely due to their smaller aperture (Fig. 4), which presumably made it more difficult for crabs to insert their dactylus far enough into the shell to reach the body of fully-retracted snails. This hypothesis is consistent with the observation that inter-population differences in aperture area and susceptibility to winkling were similarly related to snail size; whereas differences in aperture area between northern and southern snails were insignificant for the smallest individuals and then gradually increased with increasing snail size, inter-population differences in incidence of winkling were similarly small for 5 to $6 \mathrm{~mm}$ snails ( 8 vs. $4 \%$ ), greater for 6 to $7 \mathrm{~mm}$ snails ( 25 vs. $8 \%$ ), and greatest for $>7 \mathrm{~mm}$ snails (38 vs. $2 \%$ ).

The difference in aperture area between our 2 Littorina obtusata populations may be an indirect consequence of the mechanism and extent of shell thickening, or it could be a direct consequence of variation in predation risk. More specifically, enhanced calcification toward the inside of the shell, irrespective of the causal agent, may not only produce a thicker shell, but also one with a smaller aperture if the axis of coiling is unchanged (correlated-character hypothesis). Alternatively, the size and shape of the aperture might be responding adaptively to spatial variation in predation risk independently of shell thickening (predation-risk hypothesis). Deciding between these 2 possibilities could be done by comparing aperture size and shape of snails exposed to predation cues and to other stimuli that affect calcification rate, such as varying water temperature. The 'correlated-character' hypothesis predicts that aperture characteristics will be similar if shells are caused to thicken, at the same rate, by varying predation risk and water temperature, whereas the 'predation-risk' hypothesis predicts that predation-exposed snails will develop a smaller aperture than shells that have thickened to a similar degree in response to varying water temperature.

Based on the aperture-area hypothesis, one might predict that because this trait increases with increasing size, snails should become increasingly susceptible to winkling as they grow, which is only partly consistent with our observations; although the smallest snails ( 5 to $7 \mathrm{~mm}$ ) were less frequently winkled than larger individuals, as mentioned earlier, the incidence of winkling did not progressively increase with increasing size after snails reached approximately 7 to $8 \mathrm{~mm}$ shell 
height (Fig. 3). This apparent contradiction may be due to other attributes opposing the size-dependent effect of aperture area on susceptibility to winkling. For example, although larger snails have a greater shell opening, they are also able to retract further away from the plane of this opening, and they have a stronger muscle attaching them to the inside of the shell. In fact, a smaller aperture area is probably an important contributor to winkling susceptibility not because it prevents the dactylus from entering the aperture per se, but rather because it increases the minimum angle at which the dactylus can be inserted relative to the aperture plane, thereby decreasing the distance the dactylus can be inserted inside the shell relative to the plane of the aperture. We are currently conducting comparative and manipulative experiments to elucidate the simple and interactive effects of aperture area and angular retraction on snail susceptibility to winkling.

Green crabs have been reported to sometimes crush gastropod shells by inserting a dactylus through the aperture and breaking the columella or chipping the shell lip (Hughes \& Elner 1979). We did see green crabs attempt this technique during our observations, but it was never successful. If crabs did successfully use this technique during the main experiment, where a broader size range of snails was available, then the smaller aperture of southern snails may have also made them less susceptible to this crushing technique (Hughes \& Elner 1979).

\section{CONCLUSION}

Our study shows that contemporary variation in Littorina obtusata shell architecture in the GoM significantly affects predatory effectiveness of the European green crab Carcinus maenas. It indicates that shell thickness, and not spire height (or chemical defense), is likely to be responsible for the inter-population variation in $L$. obtusata susceptibility to shell-crushing predation that we observed. It also reveals that green crabs prey on larger more heavily-armored snails using an unusual and fairly complex predatory behavior, which we term winkling, and suggests that snails may be countering this novel tactic by producing (or evolving) a smaller shell aperture. Field observations and experiments are needed to quantify how frequently and by what mechanism green crabs prey on snails in nature, where more varied species and sizes of prey are available. If winkling is a significant force in this recent ecological interaction, attributes such as aperture area, aperture shape and retractability of L. obtusata may have undergone an historical shift similar to that reported for shell thickness following the green crab's invasion of the eastern coast of North America.
Acknowledgements. We thank J. I. Brookes for her assistance with morphometric measurements, as well as Drs. G. J. Vermeij, R. H. Seeley and one anonymous reviewer for helpful comments on an earlier version of the manuscript. This research was supported by NSERC Discovery (\# 249966-02) and UNB Research Fund (\#UNB 35-20) grants to R.R.

\section{LITERATURE CITED}

Boulding EG, Holst M, Pilon V (1999) Changes in selection on gastropod shell size and thickness with wave-exposure on Northeastern Pacific shores. J Exp Mar Biol Ecol 232: 217-239

Currey JD, Hughes RN (1982) Strength of the dogwhelk Nucella lapillus and the winkle Littorina littorea from different habitats. J Anim Ecol 51:47-56

DeWitt TJ, Robinson BW, Wilson DS (2000) Functional diversity among predators of a freshwater snail imposes an adaptive trade-off for shell morphology. Evol Ecol Res 2: 129-148

Ebling FJ, Kitching JA, Muntz L, Taylor CM (1964) The ecology of Lough Ine. XIII. Experimental observations of the destruction of Mytilus edulis and Nucella lapillus by crabs. J Anim Ecol 33:73-82

Elner RW (1981) Diet of green crab Carcinus maenas (L.) from Port Hebert, southwestern Nova Scotia. J Shellfish Res 1: 89-94

Elner RW, Raffaelli DG (1980) Interactions between two marine snails, Littorina rudis Maton and Littorina nigrolineata Gray, a predator, Carcinus maenas (L.), and a parasite, Microphallus similis Jägerskiold. J Exp Mar Biol Ecol 43:151-160

Endler JA (1977) Geographic variation, speciation, and clines. Princeton University Press, Princeton, NJ

Endler JA (1986) Natural selection in the wild. Princeton University Press, Princeton, NJ

Foster SA, Endler JA (1999) Geographic variation in behavior: perspectives on evolutionary mechanisms. Oxford University Press, New York

Hendrix LJ, Carter MW, Scott DT (1982) Covariance analyses with heterogeneity of slopes in fixed models. Biometrics 38:641-650

Hughes RN, Answer P (1982) Growth, spawning and trematode infection of Littorina littorea (L.) from an exposed shore in North Wales. J Molluscan Stud 48:321-330

Hughes RN, Elner RW (1979) Tactics of a predator, Carcinus maenas, and morphological responses of the prey, Nucella lapillus. J Anim Ecol 48:65-78

Huitema BE (1980) The analysis of covariance and alternatives. John Wiley \& Sons, New York

Johannesson B (1986) Shell morphology of Littorina saxatilis Olivi: the relative importance of physical factors and predation. J Exp Mar Biol Ecol 102:183-195

Kitching JA, Muntz L, Ebling FJ (1966) The ecology of Lough Ine. XV. The ecological significance of shell and body forms in Nucella. J Anim Ecol 35:113-126

Palmer AR (1981) Do carbonate skeletons limit the rate of body growth? Nature 292:150-152

Palmer AR (1985) Adaptive value of shell variation in Thais (or Nucella) lamellosa: effect of thick shells on vulnerability to and preference by crabs. Veliger 27:349-356

Palmer AR (1992) Calcification in marine mollusks: How costly is it? Proc Natl Acad Sci USA 89:1379-1382

Reid DG (1996) Systematics and evolution of Littorina, Vol 164. Ray Society, London 
Seeley RH (1986) Intense natural selection caused a rapid morphological transition in a living marine snail. Proc Natl Acad Sci USA 83:6897-6901

Smith LD (2004) Biogeographic differences in claw size and performance in an introduced crab predator Carcinus maenas. Mar Ecol Prog Ser 276:209-222

Thomas MLH, Himmelman JH (1988) Influence of predation on shell morphology of Buccinum undatum L. on Atlantic coast of Canada. J Exp Mar Biol Ecol 115:221-236

Trussell GC (1996) Phenotypic plasticity in an intertidal snail: the role of a common crab predator. Evolution 50:448-454

Trussell GC (2000a) Predator-induced plasticity and morphological trade-offs in latitudinally separated populations of Littorina obtusata. Evol Ecol Res 2:803-822

Trussell GC (2000b) Phenotypic clines, plasticity, and mor-

Editorial responsibility: Roger Hughes (Contributing Editor), Bangor, UK phological trade-offs in an intertidal snail. Evolution 54: 151-166

Trussell GC, Nicklin MO (2002) Cue sensitivity, inducible defense, and trade-offs in a marine snail. Ecology 83: $1635-1647$

Trussell GC, Smith LD (2000) Induced defenses in response to an invading crab predator: an explanation of historical and geographic phenotypic change. Proc Natl Acad Sci USA 97:2123-2127

Vermeij GJ (1982) Phenotypic evolution in a poorly dispersing snail after arrival of a predator. Nature 299:349-350

Vermeij GJ (1987) Evolution and escalation: an ecological history of life. Princeton University Press, Princeton, NJ

Zar JH (1984) Biostatistical analysis, 2nd edn. Prentice-Hall, Englewood Cliffs, NJ

Submitted: April 5, 2006; Accepted: June 6, 2006

Proofs received from author(s): January 10, 2007 